\title{
Finansal Gelişme, Ekonomik Büyüme ve Enerji Tüketiminin Çevresel Kalite Üzerindeki Etkisi: E-7 Ülkeleri Örneği ${ }^{1}$
}

\author{
Fahrettin PALA ${ }^{2}$ - Abdulkadir BARUT ${ }^{3}$
}

Başvuru Tarihi: 21.12.2020 Kabul Tarihi: 16.04.2021 Makale Türü: Araştırma Makalesi

\section{Öz}

Bu çalı̧smanın amacı E-7 ülke ekonomileri için (Türkiye, Hindistan, Çin, Brezilya, Endonezya, Rusya ve Meksika) finansal gelişmenin, ekonomik büyümenin ve enerji tüketiminin çevresel kalite üzerindeki etkisini 1990-2014 yılları arasında verileri kullanarak analiz etmektir. Bu amaç doğrultusunda, çevre kalitesi ölçütü olarak, kişi başına düşen karbondioksit emisyonu (CO2), finansal gelişme ölçütü olarak, özel sektöre verilen kredilerin GSYIH'ya oranı, ekonomik büyüme ölçütü olarak, ekonomik büyümede meydana gelen yıllık artışve enerji tüketimi ölçütü olarak da kişi başına petrol tüketimi değişkenleri kullanılmıştır. Değişkenlerin analizinde panel veri analizi yöntemi kullanılmıştır. İlk önce değişkenlerde ve modellerde yatay kesit bağımsızlığını test etmek için Breusch ve Pagan (1980), CDlm Pesaran (2004), CD ve Pesaran (2004), Ullah ve Yagamata (LMadj PUY) (2008) testleri uygulanmıştır. Değisşkenler ve modeller yatay kesit bağımlılı̆̆ içerdiğinden dolayı yatay kesit bağımlılı̆̆ın dikkate alan ikinci nesil panel birim kök testlerinden Pesaran (2007) CADF (Crosssectional Augmented Dickey Fuller) testi kullanılmıştır. Değişkenler durağan hale getirildikten sonra uzun dönem ilişkisi için Westerlund (2008), Durbin-H Eşbütünleşme testi uygulanmıştır. Uzun dönem ilişki katsayılarını tespit etmek içinde Genişletilmiş Ortalama Grup (AMG-Augmented Mean Group) tahmincisinden yararlanılmıştır. Analiz sonuçlarına göre, Türkiye, Endonezya ve Rusya ekonomileri için finansal gelişmenin çevre kalitesini artırdı̆ğ tespit edilmiştir. Ekonomik büyüme sonuçları incelendiğinde ise; Hindistan, Çin, Brezilya ve Meksika ekonomileri için ekonomik büyümenin karbon salınımını azaltarak çevre kalitesini artırdığı tespit edilmiştir. Türkiye ve Rusya içinse ekonomik büyümenin karbon salınımını artırarak çevre kalitesini azalttığı tespit edilmiştir.

Anahtar Kelimeler: Finansal Gelişme, Ekonomik Büyüme, Çevre Kalitesi ve Kuznets Eğrisi

Atıf: Pala, F. ve Barut, A. (2021). Finansal gelişme, ekonomik büyüme ve enerji tüketiminin çevresel kalite üzerindeki etkisi: E-7 ülkeleri örneği. Anadolu Üniversitesi Sosyal Bilimler Dergisi, 21(2), 347-366.

\footnotetext{
${ }^{1}$ Bu çalı̧̧ma etik kurul izin belgesi gerektirmemektedir.

${ }^{2}$ Gümüşhane Üniversitesi Kelkit Aydın Doğan Meslek Yüksek Okulu Muhasebe ve Vergi Bölümü, fahrettinpala@gumushane.edu.tr,_ORCID: 00000001-9565-8638

${ }^{3}$ Harran Üniversitesi Siverek Meslek Yüksekokulu Muhasebe ve Vergi Bölümü, kadirbarut@harran.edu.tr, ORCID: 0000-0001-8315-9727
} 


\title{
Financial Development, Economic Growth and Energy Consumption on Environmental Quality: Case of E-7 Countries
}

\author{
Fahrettin PALA ${ }^{4}$ - Abdulkadir BARUT 5
}

Submitted by: 21.12 .2020

Accepted by: 16.04 .2021

Article Type: Research Article

\begin{abstract}
The aim of this study is to analyze the effects of financial development, economic growth and energy consumption on environmental quality for the economies of E-7 countries (Turkey, India, China, Brazil, Indonesia, Russia and Mexico) using the data between 1990-2014. For this purpose, carbon dioxide emissions per capita (CO2) as a measure of environmental quality, a measure of financial development, the ratio of loans to the private sector to GDP, a measure of economic growth, an annual increase in economic growth and a measure of energy consumption per capita. per oil consumption variables are used. Panel data analysis method is used in the analysis of the variables. First, Breusch and Pagan (1980), CDlm Pesaran (2004), CD and Pesaran (2004), Ullah and Yagamata (LMadj PUY) (2008) tests are applied to test cross-section independence in variables and models. Since the variables and models contain cross-sectional dependence, the Pesaran (2007) CADF (Crosssectional Augmented Dickey Fuller) test, one of the second generation panel unit root tests that takes into account the crosssectional dependence, is used. After the variables are made stationary, Westerlund (2008), Durbin-H Cointegration test is applied for the long-term relationship. The Extended Mean Group (AMG) estimator is used to determine the long-term correlation coefficients. According to the results of the analysis, it has been determined that financial development increases the environmental quality for the economies of Turkey, Indonesia and Russia. When the economic growth results are examined; It has been determined that economic growth for the economies of India, China, Brazil and Mexico improves environmental quality by reducing carbon emissions. For Turkey and Russia, it has been determined that economic growth reduces environmental quality by increasing carbon emissions.
\end{abstract}

Keywords: Financial Development, Economic Growth, Environmental Quality and Kuznets Curve

\footnotetext{
4 Gümüşhane University Kelkit Aydın Doğan Vocational School Accounting and Tax Department, fahrettinpala@gumushane.edu.tr,_ORCID: 0000-0001-9565-8638

${ }^{5}$ Harran University Siverek Vocational School Accounting and Tax Applications Department, kadirbarut@harran.edu.tr, ORCID: 0000-0001-83159727
} 


\section{Giriş}

Ekonomik önlemler neticesinde büyüme ve kalkınma için alınan faaliyetlerden kaynaklanan artan çevresel riskler, küresel meseleler haline gelmiş ve çevre ekonomisi ve sürdürülebilir kalkınma adına tartışmalı bir araştırma alanı olarak ortaya çıkmıştır (Shoaib, Rafiqu, Nadeem ve Huang, 2020, s.12461). Son yıllarda küresel ısınma insanlığın karşı karşıya kaldığı büyük bir sorundur. Bu ortak fikir birliği bilim adamları, kamu otoriteleri ve kamuoyu arasında bir gerçektir (Sekali ve Bouzahzah, 2019, s.67).

Çevresel bozulma evrensel bir konu olup, tüm dünya çevresel kalitenin bozulmasından kaynaklanan tehditlere maruz kalmaktadır. Çevresel kalitenin bozulmasında en büyük paya sahip olan karbondioksit (CO2) emisyonu, sera etkisinin ana kaynaklarından biridir. CO2 emisyonlarının çoğu; kömür, petrol ve gaz gibi fosil yakıt tüketiminden kaynaklanmaktadır. Bir ülkedeki CO2 emisyonların; gelir düzeyi, enerji tüketimi, nüfus, dış ticaret, finansal kalkınma ve benzeri birçok faktöre bağlı olduğu düşünülmektedir (Sehrawat, Giri ve Mohapatra, 2015, s.665-666). Tüm bunların sonucunda, özellikle içinde bulunduğumuz yüz yılda çevresel problemler dünyayı tehdit etmeye başlayınca küresel anlamda çözüm arayışları içerisine girilmiştir (Çetin, Kırcı, Saygın ve Alaşahan, 2018, s.27).

Ekonomik kalkınma yüksek bir yaşam standardı vaat eden ancak aynı zamanda çevresel bozulmaya neden olan uzun bir süreçtir. Kuznets tarafından kurulan, Grossman v e Krueger (1995) tarafından önerilen çevresel kuznets eğrisi, ekonomik büyüme ve çevresel bozulma arasındaki ilişkinin ters-U şeklinde olduğunu varsaymaktadır. Buna göre ekonomik büyüme başlangıçta çevresel bozulmayı artırmakta, daha sonra kişi başına bir eşik gelir noktasından sonra ise azaltmaktadır (Stern, 2004; Carson, 2010; Shahbaz, Shahza, Ahmad ve Alam, 2016). Bu durum, ekonomik büyümenin başlangıç dönemlerinde daha fazla enerji kullanımına ihtiyaç duyulacağından çevre kirliliğini artırarak çevresel kalitenin azalmasına neden olacaktır. Sonraki dönemlerde ise ekonomik büyümenin devam etmesi ekonomide yapısal değişim sürecini başlatacak, üretim ve tüketimin yapısını değiştirerek, temiz çevreye olan talebi artıracaktır. Böylece enerjiyi daha verimli bir şekilde kullanabilen temiz teknolojiler gelişecektir. Başak bir ifadeyle çevresel kuznets eğrisi hipotezine göre, uzun vadede ekonomik büyümenin çevre kalitesi üzerindeki etkisinin pozitif yönde olacağı vurgulanmaktadır (Koçak, 2017, s.537).

Finansal gelişme, hızlı ekonomik büyümenin yanı sıra çevrede CO2 emisyonunun azaltılmasında hayati ve potansiyel öneme sahip bir faktördür. Finans sektörleri enerji alanındaki teknolojik ilerlemeyi canlandırarak enerji tüketimini ve CO2 emisyonlarını etkileyebilirler (Yang, Zhang ve Meng, 2015, s.334). Bir ülkede finans sektörünün gelişmesi, daha yüksek bir gelir artışı elde edilmesinde önemli bir rol oynar ve çevresel kaliteyi önemli ölçüde etkiler (Jalil ve Feridun, 2011). Literatürde çevre kirliliği ölçütü olarak genellikle CO2 salınımı kullanıldığından dolayı çalışmada da bu değişken çevre kalitesini ölçmede kullanılmıştır (Çetin vd., 2018, s.26).

Çalışmanın amacı, çevre kalitesi E-7 ülke ekonomileri açısından ele alınarak finansal gelişmenin, ekonomik büyümenin ve enerji tüketiminin çevresel kalite üzerindeki etkisini panel veri analizi ile incelemektir. Çünkü son yıllarda teknolojide yaşanan hızlı değişim ve gelişim çevre kalitesi üzerinde etkili olabilmektedir. Çevresel kalitenin bozulması başta iklim ve canlılar olmak üzere birçok unsur üzerinde olumsuz etkilere neden olduğundan dolayı önem arz eden bir konudur. Bu nedenden dolayı bu çalışma yapılmıştır. Çalışmada E-7 ülkelerinin tercih edilme nedeni ise son yıllarda bu ülkelerin hızla yükselen ve büyüyen ekonomiye sahip olmaları, özellikle de Çin ekonomisinin yer alması etkili olmuştur.

Çalışma altı bölümden oluşmaktadır. Birinci bölümde giriş kısmı açılandıktan sonra ikinci bölümde araştırma kapsamında yer alan finansal gelişme, ekonomik büyüme ve çevre kalitesi arasındaki ilişki ayrıntılı bir şekilde açıklanmıştır. Üçüncü bölümde teorik ve ampirik literatüre değinilmiştir. Dördüncü bölümde araştırmanın yöntem ve metodoloji kısmı açıklanmıştır. Beşinci bölümde bulgular ve yorumları açıklandıktan sonra, altıncı ve son bölümde ise sonuç ve değerlendirme yapılarak çalışma tamamlanmıştır. 


\section{Finansal Gelişme ile Çevresel Kalite Arasındaki ilişki}

Büyüme üzerine yapılan ilk çalışmalar, genellikle sadece sermaye, emek ve teknolojik ilerlemenin ekonomik büyüme üzerindeki etkisine değinmiştir. Bununla birlikte, son 20 yıldaki teorik gelişmeler, finansal faktörlerin ve çevresel kaynakların da modern ekonomik büyümede önemli bir rol oynadığını göstermiştir (Li vd., 2015, s.9396).

Güçlü finansal gelişme, ekonomik ve diğer türden kalkınma için kilit faktörlerden biri olan bir ekonominin finansal sektörlerini canlandırır. Ekonomik büyümeyi canlandırabilen finans sektörü, enerji tüketiminin artmasına ve/veya azalmasına ve çevresel kalitenin bozulmasına ve/veya iyileştirmesine neden olabilmektedir (Zafar vd., 2019, s.13250).

Finansal gelişme ile çevre arasındaki ilişki üzerine yapılan ilk ampirik çalışmalar Aufderheide ve Rich (1988) ve Schmidheiny ve Zorraquin'in (1998) çalışmalarıdır. Aufderheide ve Rich (1988), çevre kalitesini iyileştirmede çok taraflı bankaların rolünü vurgulamışlardır. Dünya Bankası tarafından sağlanan mali yardım mekanizmasının, ödünç verilebilir fonlar sağlarken çoğu zaman çevresel yönleri göz ardı ettiğini iddia etmişlerdir. Hatta bu konuya örnek olarak toprak erozyonu ile ilgili Hindistan'daki kauçuk projesinden kaynaklanan orman alanlarının ve pamuk üretiminden kaynaklanan tarım alanlarının bozulmasını vermişlerdir. Bu tehlikelerin nedeni, ciddi çevre sorunları dikkate alınmadan müşterilere kredi sağlanmasıydı. Schmidheiny ve Zorraquin'de (1998) finansal kuruluşların kısa vadeli krediler verilmesini teşvik ettiğini ancak doğal kaynakların tükenmesine neden olan çevresel sorunları görmezden geldiklerini belirtmişlerdir (Tahir vd., 2021, s.8090-8091).

Günümüzde küresel ısınma, insanlığın karşılaştığı büyük bir zorluktur. Bu ortak fikir birliği bilim adamları, kamu otoriteleri ve kamuoyu arasında bir gerçektir. Bir dereceye kadar bu fikir birliği, insan faaliyetlerinin, özellikle malların ve hizmet faaliyetlerinin üretiminin, özellikle CO2 olmak üzere sera gazı (GHG) emisyonları yoluyla bu küresel ısınmadan sorumlu olduğu gerçeğine dayanmaktadır. Yapılan ampirik çalışmalarda (Kraft ve Kraft, 1978; Soytaş ve Sari, 2003; Lee ve Chiang, 2008) insan faaliyetinin, yani fosil enerjilerin tüketimi yoluyla mal ve hizmet üretiminin, CO2 emisyonlarının ana kaynağı olduğunu göstermektedir (Sekali ve Bouzahzah, 2019, s.67).

Finansal gelişme çevreyi çeşitli şekillerde etkileyebilir. Finansal gelişme ve yatırım kredileri, yatırım düzeyini, sanayi sektörünün gelişimini ve ekonomik büyümeyi ve dolayısıyla enerji talebini ve artan sera gazı emisyonlarını arttırır (Sadorsky, 2010; Sekali ve Bouzahzah, 2019). Aynı şekilde, kredilerin artırılması, hane halkının satın alma gücünü artıracağından ev aletleri, otomobiller vb. aletleri kolaylıkla satın almalarına neden olacak ve böylece enerji talebini ve artan sera gazı emisyonlarını arttıracaktır (Karanfil, 2009; Sekali ve Bouzahzah, 2019).

Finansal gelişme ile $\mathrm{CO} 2$ emisyonları arasındaki ilişkiyi açıklayan başlıca iki araştırma türü vardır. Bunlardan biri, finansal gelişme ile $\mathrm{CO} 2$ emisyonları arasında negatif yönlü ilişki olduğunu açıklayan araştırmalar, ikincisi ise finansal gelişme ile çevre arasındaki ilişkide, finansal gelişmenin artmasıyla çevre kalitesinin düştüğünü ortaya koyan araştırmalardır (Zafar vd., 2019, s.13250).

\section{Ekonomik Büyüme ile Çevresel Kalite Arasındaki iliş̧i}

Çevresel kalite ve ekonomik büyüme arasındaki ilişki, 1970'lerden sonra Club of Rome üyelerinin The Limits to Growth'de dramatik çevresel koşullardan kaçınmak için sıfır büyüme veya kararlı durum ekonomisini tartışmalarından sonra kapsamlı bir incelemeye tabi tutulmuştur. Beckerman (1992) ise teknolojik ilerlemenin doğal kaynaklara olan bağımlılı̆̆ azaltacağını ve sürekli büyümeye izin vereceğini iddia etmiştir. $\mathrm{Bu}$ tartışmada, Shafik'in (1994) işaret ettiği gibi, bir argümanı veya diğerini destekleyen ampirik kanıtlar yoktu, bu nedenle tartışma, uzun yıllar boyunca mevcut çevresel verilerin eksikliğinden dolayı uzun bir süre tamamen 
teorik bir temelde kalmıştır. Son olarak, kükürt dioksit, azot oksit emisyonları ve karbondioksit gibi çevresel göstergeleri uygulayan ampirik çalışmalardaki kanıtlar, gelirle ters bir U ilişkisi olduğunu göstermiştir. Böylece çevresel bozulma büyümenin ilk aşamalarında daha da kötüleşir, ancak sonunda bir zirveye ulaşır ve gelir "dönüm noktası" denilen bir eşik düzeyini geçtikçe düşmeye başlar. Bu ilişki, 1950'lerde gelir ve eşitsizlik arasında benzer bir ilişki olduğunu ilk kez gözlemleyen ve öne süren Simon Kuznets'ten sonra Çevresel Kuznets Eğrisi (EKC) olarak tanımlanmıştır (Cialani, 2007).

Ekonomik büyüme ile çevre kirliliği arasındaki ilişkiyi analiz etmek için en yaygın kullanılan yöntem EKC hipotezidir. EKC, ekonomik kalkınmanın erken aşamasında, ortalama gelir gelişme aşamasında belirli bir seviyeye ulaşana kadar çevrenin kalitesinin düşme eğiliminde olduğunu ve daha sonra iyileştiğini savunuyor. Çevresel Kuznets eğrisi hipotezinin geçerliliği, yıllar boyunca farklı çalışmalarla geniş çapta incelenmiştir. Araştırma sonuçları; farklı veri türleri, kirletici madde türleri, ülke ve yaklaşım seçimleri gibi nedenlerden dolayı çeşitlilik göstermektedir (Jiang vd., 2020, s.3).

EKC hipotezine dayanarak yapılan (Grossman ve Krueger, 1991; Lieb, 2003; Babu ve Datta, 2013) birçok çalışma ekonomik büyüme ile çevre kirliliği arasındaki ilişkinin $\mathrm{N}$ şeklinde olduğunu ortaya koymuştur. Tersine çevrilmiş U-biçimli modelle karşılaştırıldığında, N-biçimli model, ekonomik kalkınmanın ilk aşamalarında, çevresel baskının ekonomik büyümeyle artma eğiliminde olduğunu ve daha sonra azaldığını, ancak kritik bir ekonomik gelişme düzeyine ulaştıktan sonra tekrar yükseldiğini gösterir (Jiang vd., 2020, s.3). EKC hipotezi hakkındaki farklı görüşlerden biride, kirlilik ve büyüme arasında monoton olarak artan bir eğri olduğudur (Holtz-Eakin ve Selden, 1995; Al-Mulali vd., 2015).

\section{Enerji Tüketimi ile Çevresel Kalite Arasındaki iliş̧ki}

Çevre sorunlarının çoğu enerji kullanımından kaynaklanmaktadır. Çünkü enerjinin çevreye zarar vermeden taşınması, üretilmesi ve tüketilmesi imkânsızdır. Yenilenemeyen kaynaklardan enerji üretimi, biyotik bileşen kadar çevre için de çok tehlikeli olan yoğun tipte zararlı zehirli gazlar ürettiği için çevre üzerinde tehlikeli etkilere sahiptir. Ekosistem, çevredeki ortamı dengede tutmak için birbirleriyle etkileşime giren biyotik ve abiyotik bileşenlerden oluşur (Munir ve Riaz, 2019).

Enerji tüketiminin çevre kalitesine etkisi konusunda farklı görüşler vardır. Birincisi, petrolün sürdürülebilir ekonomik büyümeyi teşvik eden, işletme maliyetini düşüren, emtia arz ve talebini artıran, serbest ticareti teşvik eden ve ülkelerdeki istihdam koşullarını iyileştirmeyi amaçlayan en bol enerji kaynaklarından biri olduğunu savunan (Meadows vd., 1972 ; Akbostanci vd., 2009; Al-Amin vd., 2009; Akin, 2014) görüştür. İkincisi, enerji tüketiminin çevre üzerinde ciddi etkileri olduğunu savunan görüştür. Çevreciler ve ekonomistler, petrol, kömür, gaz ve elektrik yoluyla enerji tüketiminin, yüksek tüketim oranı nedeniyle büyük miktarda atık ürettiğini ve dünyanın çevre koşullarını bozduğunu savunmaktadırlar. Aynı zamanda karbon vergisi fikrine de karşı çıkıyorlar çünkü ne kadar karbon üretildiğini ölçmenin oldukça zor olduğunu ve bu nedenle hangi seviyede karbon vergisinin uygulanacağını bilmenin zor olduğunu ifade etmektedirler (Munir ve Riaz, 2019). Bununla birlikte literatürde enerji yanmasının CO2 emisyonları üzerinde olumlu etkisi olduğunu savunan Irfan ve Shaw ( 2017 ) ile Saidi ve Hammami ( 2015 ) görüşlerde vardır.

\section{Literatür Taraması}

Literatürde çevre kalitesi (kirliliği) ve buna etki eden unsurlar önemli ölçüde tartışılmaktadır. Özellikle Kuznets tarafından kurulan, Grossman ve Krueger (1995) tarafından önerilen çevresel kuznets eğrisi (EKC) olarak bilinen çevresel bozulma ve ekonomik gelişme arasındaki ilişki hakkında geniş bir literatür mevcuttur (Shahbaz vd., 2016, s.353). Literatürde mevcut olan önemli bazı çalışmalar aşağıdaki gibi özetlenmiştir. 
Shoaib vd. (2020), 1999-2013 yıllı dönemsel verilerini kullanarak G8 ve D8 ülkelerinde, finansal kalkınma ve $\mathrm{CO} 2$ emisyonu arasındaki ilişkiyi panel veri analizi ile incelemişlerdir. Analiz sonuçları, finansal gelişmenin uzun vadede $\mathrm{CO} 2$ emisyonu üzerinde istatistik düzeyinde anlamlı ve olumlu bir etkiye sahip olduğunu ortaya koymuştur. Khan, Peng ve Li (2019) çalışmalarında, 193 ülkenin 1990-2017 yılları arasındaki verilerini kullanarak, finansal gelişmenin, ekonomik büyümenin, enerji tüketiminin ve $\mathrm{CO} 2$ emisyonun birbirleri üzerindeki etkisini sistem GMM yönetimi ile incelemişlerdir. Analiz sonuçları, finansal gelişmenin, ekonomik büyümenin, enerji tüketiminin ve $\mathrm{CO} 2$ emisyonun birbirinden etkilendiğini, ancak finansal gelişmeyi azaltan enerji tüketimi haricinde, diğerlerinin yüksek çevre kirliliği yayılımına neden olduğunu ortaya koymuştur. Sonuçlar ayrıca, Kuznet eğrisinin geçerli olduğunu da göstermiştir.

Sekali ve Bouzahzah (2019), 1980-2015 yılları arasındaki verileri ve ARDL modellemesini kullanarak, finansal gelişmenin Fas'ta çevresel kalite üzerindeki etkilerini incelemişlerdir. Analiz sonuçları, ekonomik büyüme, enerji tüketimi, finansal gelişme ve CO2 emisyonları arasında uzun vadeli bir ilişki olduğunu ortaya koymuştur. Temelli ve Şahin (2019) çalışmalarında, yükselen 10 piyasa ekonomisi için 1995-2014 yılları arasındaki verileri kullanarak, finansal gelişmenin, ekonomik büyümenin ve teknolojik gelişmenin çevre kalitesine etkisini panel veri analizi ile incelemişlerdir. Eş bütünleşme test sonuçları, değişkenler arasında uzun vadede ilişki olduğunu ortaya koymuştur. Panelin genelinde finansal ve teknolojik gelişmenin $\mathrm{CO} 2$ emisyonu üzerinde herhangi bir etkisinin olmadığını, ancak ekonomik büyümenin CO2 emisyonu üzerinde olumlu ve anlamlı etkisinin olduğunu ortaya koymuştur.

Çetin vd. (2018), Türkiye ekonomisi için, ekonomik büyümenin, finansal gelişmenin, enerji tüketiminin ve dış ticaretin çevre kirliliği üzerindeki etkisini 1960-2013 yılları arasındaki verileri kullanarak zaman serisi analizi ile incelemişlerdir. Analiz sonuçları, uzun vadede değişkenler arasında bir nedensellik ilişkisi olduğunu, bu ilişkinin yönünün CO2 salınımından enerji tüketimine, dış ticaretten de CO2 salınımına doğru olduğunu ortaya koymuştur. Şahin (2018) çalışmasında, D-8 ülke ekonomileri için 1990-2014 yılları arasındaki verileri kullanarak finansal gelişme ve ticari açıklı̆̆ın çevre kalitesi üzerindeki etkisini panel veri analizi yöntemi ile incelmiştir. Analiz sonuçları, değişkenler arasında eş bütünleşme ilişkisi olduğunu ortaya koymuştur. $\mathrm{Bu}$ ilişkide, finansal gelişmenin, ekonomik büyümenin ve enerji tüketiminin CO2 salınımı üzerindeki etkisinin anlamlı ve pozitif yönde olduğunu, ticari açıklı̆ın $\mathrm{CO} 2$ üzerindeki etkisinin ise anlamsız ve negatif olduğunu ortaya koymuştur.

Dar ve Asif (2018), Türkiye ekonomisi için, 1960-2013 ylllı dönemsel verilerini kullanarak finansal gelişme, enerji kullanımı ve ekonomik büyümenin karbon emisyonları üzerindeki etkisini incelemişlerdir. Analiz sonuçları, uzun vadede değişkenler arasında eş-bütünleşme ilişkisinin olduğunu ortaya koymuştur. Bu ilişkide finans sektörünün gelişimi çevresel kaliteyi artırırken, enerji kullanımı ve ekonomik büyümenin ise çevresel kaliteyi düşürdüğü belirtilmiştir. Shahbaz vd. (2016) çalışmalarında, Pakistan ekonomisi için, 1985Q1-2014Q4 dönemleri arasındaki verileri kullanarak, finansal gelişmenin çevre kalitesi üzerindeki asimetrik etkisini ARDL testi incelemişlerdir. Analiz sonuçları, enerjinin verimsiz kullanılmasının çevre kalitesini olumsuz yönde etkilediğini ortaya koymuştur. Ayrıca banka temelli finansal kalkınmanın da çevre kalitesi üzerinde etkili olduğunu da ortaya koymuştur. CO2 emisyonları ile ekonomik büyüme, enerji tüketimi ve finansal gelişme (banka bazlı ve borsa bazlı) arasında pozitif bir korelasyon olduğunu ifade etmişlerdir.

Jamel ve Derbali (2016), 8 Asya ülkesinin 1991-2013 yılları arasındaki verilerini kullanarak, enerji tüketimi ve ekonomik büyümenin $\mathrm{CO} 2$ emisyonları üzerindeki etkisini panel veri analizi yöntemi ile incelemişlerdir. Analiz sonuçları, ekonomik büyümenin ve enerji tüketiminin çevresel bozulma üzerinde olumlu ve önemli bir etkisi olduğunu ortaya koymuştur. Sonuçlar ayrıca, enerji tüketimi ile ekonomik büyüme ve çevresel bozulma arasında çift yönlü bir nedensellik ilişkisi olduğunu da ortaya koymuştur. Li, Zhang ve Ma (2015) çalışmalarında, finansal gelişme, çevresel kalite ve ekonomik büyüme arasındaki ilişkiyi, 102 ülkenin 19802010 yılları arasındaki verilerini kullanarak genelleştirilmiş momentler (GMM) tahmini yöntemi ile 
incelemişlerdir. Analiz sonuçları üç temel sonuç ortaya koymuştur. Bunlardan birincisi, hem finansal gelişmenin hem de çevresel kalitenin ekonomik büyüme üzerinde önemli bir etkisi olduğu, ikincisi, finansal gelişme ile ekonomik büyüme arasında anlamlı ve sağlam bir "ters U-şekli” ilişkinin olduğu, üçüncüsü ise, ekonomik büyüme ve karbon emisyonları arasında önemli ve sağlam bir "ters U-şekli" ilişkinin olduğudur.

Sehrawat vd. (2015), Hindistan ekonomisi için 1971-2011 yılları arasındaki verileri kullanarak, finansal kalkınmanın, ekonomik büyümenin ve enerji tüketiminin çevre kalitesi üzerindeki etkisini panel veri analizi ile incelemişlerdir. Analiz sonuçları, çevresel bozulmaya katkıda bulunan başlıca faktörlerin, ekonomik büyüme, enerji tüketimi, finansal gelişme ve kentleşme olduğu sonucunu ortaya koymuştur. Ayrıca Hindistan ekonomisi için çevresel Kuznets eğirişinin geçerli olduğunu da ifade etmişlerdir. Yang vd. (2015) çalışmalarında, Çin ekonomisi için, 1978-2012 yılları arasındaki verileri kullanarak finansal gelişme ve ekonomik büyümenin çevre kalitesi üzerindeki etkisini incelemişlerdir. Analiz sonuçları, uzun ve kısa vadede değişkenler arasında Kuznets eğrisinin geçerli olduğunu, uzun vadede finansal gelişmenin çevre kirliliğini azalttığını ortaya koymuştur. Aynı şekilde uzun vadede ekonomik büyümenin çevre kalitesi üzerindeki etkisinde finansal gelişmişliğin zayıflatıcı moderatör etkisi olduğunu da ifade etmişlerdir.

\section{Araştırmanın Yöntemi}

\section{Veri Seti}

$\mathrm{Bu}$ çalışmada; finansal gelişmenin, ekonomik büyümenin ve enerji tüketimin çevre kalitesi üzerindeki etkisi (Türkiye, Çin, Hindistan, Endonezya, Brezilya, Rusya ve Meksika) E-7 ülke ekonomileri bağlamında ele alarak incelenmektedir. Veri seti 1990-2014 dönemi yıllık verileri kullanılarak oluşturulmuştur. Çalışmada veri setinin 2014 yılında sınırlandırılmasının nedeni, karbondioksit salınımı verisinin 2014 yılına kadar olmasıdır. Çalışmada kullanılan model (1) nolu eşitlikteki gibidir.

$\mathrm{CO} 2=f(\mathrm{FD}, \mathrm{GDP}$, Energy $)$

Modelde; çevre kalitesi ölçütü olarak, kişi başına düşen karbondioksit emisyonu (CO2), finansal gelişmeyi temsilen (FD), özel sektöre verilen kredilerin GSYİH'ya oranı, ekonomik büyümeyi temsilen (GDP), ekonomik büyümede meydana gelen yıllık artış, enerji tüketimini temsilen (Energy), kişi başına petrol tüketimi kullanılmıştır. Çalışmada kullanılan verilere Dünya Bankası veri tabanından ulaşılmıştır. Ayrıca çalışmanın verileri etik kurul izni gerektiren veri grubunda olmadığından etik kurul onayı gerektirmemektedir.

\section{Metodoloji}

\section{Yatay Kesit Bağımsızlığının ve Homojenliğin Test Edilmesi}

Ülkeler arasındaki entregrasyonun artması ile birlikte, bir ülkede veya ekonomide meydana gelen olumsuz bir durumun diğer ülke veya ekonomilerde de etkisini göstermesi beklenmektedir. Bu bağlamda ekonometrik analizler yapılırken değişkenler arasındaki yatay kesit bağımsızlığının göz önünde bulundurulması gerekmektedir. Bu nedenle değişkenlerde ve modellerde yatay kesit bağımsızlı̆̆ını test eden Breusch ve Pagan (1980) LM, Pesaran (2004) LM, Pesaran (2004) CD ve Pesaran, Ullah ve Yagamata (2008) testleri geliştirilmiştir.

Berusch ve Pagan (1980), kesitler arasında yatay kesit bağımlılığı varlığını test etmek için Lagrange Çarpanı (LM) test istatistiğine dayanmaktadır.

$$
L M=T \sum_{i=1}^{N-1} \cdot \sum_{J=\dot{I}+1}^{N} p_{i j^{2}}
$$


Pesaran (2004) yatay kesitin sayıca çok fazla olduğu durumlar için Breusch ve Pagan (1980) LM testini ölçeklendirmiş ve denklemi (3) aşağıdaki şekilde genişletmiştir.

$=\sqrt{\frac{1}{N(N-1)}} \sum_{i=1}^{N-1} \cdot \sum_{J=i+1}^{N} p_{i j^{2}}-1$

Pesaran (2004), LM ve CDLM testlerinde olası boyut bozulması problemine yönelik olarak CD test istatistiğini geliştirmiştir.

$C D_{L M}=\sqrt{\frac{2 T}{N(N-1)}} \sum_{i=1}^{N-1} \cdot \sum_{J=\dot{I}+1}^{N} P_{i J^{2}}$

Pesaran vd. (2008) tarafından geliştirilen bir diğer yatay kesit bağımlılık testide (5) nolu eşitlikte görülen sapması düzeltilmiş $\mathrm{LM}_{\text {adj }}$ testidir.

$=\sqrt{\frac{2 \boldsymbol{T}}{N(N-1)}} \sum_{\mathrm{i}=1}^{\mathrm{N}-1} \cdot \sum_{\mathrm{J}=\mathrm{i}+1}^{\mathrm{N}} \quad \mathrm{T}_{i j} \frac{\mathrm{T}-\mathrm{k} \quad \mathrm{p}_{\mathrm{ij}^{2}-\mathrm{uT}_{\mathrm{ij}}}}{\sqrt{\boldsymbol{v}^{\boldsymbol{T}_{i j}}}}$

Peseran, Ullah ve Yagamata (2008), Peseran (2004) LM, Peseran (2004) CD ve Breusch ve Pagan (1980) LM, testlerinde olasılık değerinin \%5’ten küçük olması durumunda yatay kesit varlığını reddeden temel hipotez kabul edilmemektedir. Bu bağlamda Tablo1 ve Tablo 2 incelendiğinde değişken ve modellerin yatay kesit bağımlılığı içerdiği tespit edilmiştir. Yatay kesit bağımsızlığı paneli oluşturan birimlerden herhangi birinde yaşanan bir şokun diğer tüm birimlerin etkilenme derecelerinin aynı olması ve ülkelerin herhangi birinde yaşanan bir makroekonomik şoktan paneli oluşturan diğer ülkelerin etkilenmediği varsayımına dayanmaktadır (Koçbulut ve Altıntaş, 2016, s.152). Ancak ülkeler arasındaki entregrasyonun artması ile birlikte, bir ülkede veya ekonomide meydana gelen bir şoktan diğer ülke veya ekonomilerde de etkilenebileceği bir gerçektir. Bundan hareketle çalışmada uygun ekonometrik testlerin seçilmesi amacı ile yatay kesit bağımlılı̆̆ı testi yapılmış, değişken ve modellerde yatay kesit bağımlılığı olduğundan dolayı yatay kesit bağımlılığını dikkate alan testler kullanılmıştır.

Tablo1

Değişkenlere Ait Yatay Kesit Bağımsızlı̆̆ı Testi Sonuçları

\begin{tabular}{|c|c|c|c|c|c|c|c|c|}
\hline & \multicolumn{2}{|c|}{$\begin{array}{c}\text { LM (Breusch, Pegan } \\
1980)\end{array}$} & \multicolumn{2}{|c|}{ CDlm (Pesaran 2004) } & \multicolumn{2}{|c|}{ CD (Pesaran 2004) } & \multicolumn{2}{|c|}{ LMadj (PUY, 2008) } \\
\hline & İstatistik & Olasillk & İstatistik & Olasılık & İstatistik & Olasilık & İstatistik & Olasilık \\
\hline & Değeri & Değeri & Değeri & Değeri & Değeri & Değeri & Değeri & Değeri \\
\hline $\mathrm{C} 02$ & 59,445 & $0.000^{* * *}$ & 5,778 & $0.000^{* * *}$ & $-0,719$ & 0,236 & 3,65 & $0.000^{* * *}$ \\
\hline FD & 58,21 & $0.000^{\star * *}$ & 5,742 & $0.000^{\star * *}$ & $-2,416$ & $0.008^{* * *}$ & 2,599 & $0.005^{* * *}$ \\
\hline GDP & 59,767 & $0.000^{* * *}$ & 5,982 & $0.000^{* * *}$ & $-1,862$ & $0.003^{* * *}$ & 1,937 & $0.026^{* *}$ \\
\hline Energy & 48,788 & $0.001^{* * *}$ & 4,288 & $0.000^{* * *}$ & $-2,118$ & $0.017^{* *}$ & $-0,823$ & 0,795 \\
\hline
\end{tabular}

Not: ${ }^{* * *}, * *$ sırasıyla \%1 ve \%5 önem düzeylerinde yatay kesit bağımlılığııı ifade etmektedirler. 
Tablo 2

Modele Ait Yatay Kesit Bağımsızlı̆̆ı Testi Sonuçları

\begin{tabular}{|c|c|c|c|c|c|c|c|c|}
\hline \multirow{2}{*}{$\begin{array}{l}\mathrm{CO} 2=f \\
(\mathrm{FD}, \mathrm{GDP}, \\
\text { Energy) }\end{array}$} & \multicolumn{2}{|c|}{$\begin{array}{c}\text { LM (Breusch, Pegan } \\
1980)\end{array}$} & \multicolumn{2}{|c|}{ CDlm (Pesaran 2004) } & \multicolumn{2}{|c|}{ CD (Pesaran 2004) } & \multicolumn{2}{|c|}{ LMadj (PUY, 2008) } \\
\hline & İstatistik & Olasılık & İstatistik & Olasılık & İstatistik & Olasılık & $\overline{\text { İstatistik }}$ & Olasılık \\
\hline & Değeri & Değeri & Değeri & Değeri & Değeri & Değeri & Değeri & Değeri \\
\hline & 41,61 & $0.005^{\star * *}$ & 3,18 & $0.001^{\star * *}$ & 2,008 & $0.022^{\star *}$ & 4,178 & $0.000^{* * *}$ \\
\hline
\end{tabular}

Not: ${ }^{* * *} \% 1$ önem düzeyinde yatay kesit bağımlılı̆̆ını ifade etmektedir.

Eğim katsayılarının yatay kesitler arasında farklı olup olmadığını test etmek için Pesaran ve Yamagata (2008) tarafından delta testi geliştirilmiştir. Bu testin temel hipotezi eğim katsayıları homojendir yönünde olup olasılık değerinin \%5’ten küçük olması modelde eğitim katsayılarının homojen olmadığı anlamına gelmektedir. Bu bağlamda Tablo 3 incelendiğinde modeldeki eğim katsayılarının homojen olmadığı görülmektedir.

Pesaran ve Yamagata (2008), homojenliğin büyük örneklem açısından test edilmesi için denklem (6), küçük örneklem açısından test edilmesi için de denklem (7) geliştirilmiştir.

$$
\begin{aligned}
& =\sqrt{N}\left(\frac{N^{-1} S-k}{2 k}\right) X^{2} k \\
& \Delta_{a d j}=\sqrt{N}\left(\frac{N^{-1} S-k}{v(T, k)}\right) \sim N(0,1)
\end{aligned}
$$

Tablo 3

Modele Ait Homojenlik Testi Sonuçları

\begin{tabular}{lrrrr}
\hline & \multicolumn{2}{c}{ Delta_tilde } & \multicolumn{2}{c}{ Delta_tilde adj } \\
\cline { 2 - 5 } $\mathrm{CO} 2=f(\mathrm{FD}$, & Olasilık Değeri & İstatistik Değeri & Olasilık Değeri \\
$\mathrm{nDP}$, Energy) & İstatistik Değeri & $0.000^{* * *}$ & 13,488 & $0.000^{* * *}$ \\
\hline
\end{tabular}

Not: ${ }^{* * \star}, \% 1$ önem düzeyinde heterojenliği ifade etmektedir.

Değişkenlerin ve modellin yatay kesit bağımlılığı içermesi ve modelin eğim kat sayılarının heterojen olması nedeniyle, kullanılacak ekonometrik testlerin yatay kesit bağımlılığını ve heterojenliği dikkate alan testler olmalıdır.

\section{Değisskenlerin durağanlıklarının incelenmesi}

Serilerin durağanlığını test etmek için yatay kesit bağımlılığını dikkate alan 2. nesil panel birim kök testlerinden Pesaran (2007) CADF (Crosssectional Augmented Dickey Fuller) testi kullanılmıştır. Bu teste önce her kesit ( ülke, firma, vb.) için ayrı ayrı durağanlı hesaplanmakta ve daha sonra bu kesitlerin aritmetik ortalaması ile panelin durağanlığı hesaplanmaktadır. Elde edilen panel test istatistikleri ve CADF istatistikleri Peseran (2008) tarafından hesaplanan kritik değerler ile karşılaştırılmakta ve kritik değerler test istatistiklerinden büyük olduğunda temel hipotez reddedilmektedir. Temel hipotezin reddedilmesi ise panelde en az bir birimin durağan olduğu anlamına gelmektedir. 
CADF testi ilk olarak her bir değişken birimi için birim kök parametresini hesaplar, daha sonra genel panel için geçerli olan birim kök test istatistiklerine (CIPS) ulaşılır. CIPS’e ait denklem aşağıda verilmiştir.

$$
\text { CIPS }=\frac{1}{N} \sum_{i=1}^{N} p i
$$

Tablo 4

CADF Panel Birim Kök Testi Sonuçları

\begin{tabular}{lcc}
\hline & $\mathrm{I}(0)$ & $\mathrm{I}(1)$ \\
\hline CO2 & $-2,17$ & $-4.405^{* * *}$ \\
FD & $-3.127^{* * *}$ & $-2.861^{* * *}$ \\
GDP & $-3.571^{* * *}$ & $-3.536^{* * *}$ \\
Energy & $-1,656$ & $-3.498^{* * *}$ \\
\hline
\end{tabular}

Not: Panel istatistiği kritik değerleri, -2.57 (\%1), $-2.33(\% 5)$ ve -2.21 (\%10) (Pesaran 2007, table II(b), p:280) . ${ }^{* * *, * * *}$, sırasıyla \%1, $\% 5$ ve \%10 önem düzeyinde durağanlığı ifade etmektedirler.

Tablo 4 incelendiğinde; CO2 ve energy değişkenlerinin $\mathrm{I}(0)$ seviyesinde değerinde durağan olamadığı yani birim köklü olduğu buna karşın birinci farkları alındığında değişkenlerin I(1) seviyesinde durağanlaştığı görülmektedir. FD ve GDP değişkenleri ise I(0) seviyesinde durağan oldukları görülmektedir.

\section{Uzun dönem ilişkisinin incelenmesi}

Durbin-H Eş-bütünleşme testi, sonuç (bağımlı) değişkenin I(1) seviyesinde anlamlı olması, tahmin (bağımsız) değişken veya değişkenlerin I(1) veya I(0) düzeyinde anlamlı olması durumunda panel eş-bütünleşme analizine izin vermekte ve bu durumda ortak olan faktörler dikkate alınmaktadır (Weterlund, 2008).

Westerlund (2008) çalışmasında, eş-bütünleşme ilişkisinin olup olmadığını Durbin-H Eş-bütünleşme panel testi ve Durbin-H grup testleri ile incelemiştir. Durbin-H grup testindeki kesitler arasında otoregresif parametrenin ayırt edilmesine izin vermektedir. Bu testte eş-bütünleşme ilişkisinin var olmadığ $\mathrm{H} 0$ hipotezi ile, en az sayıda bölüm için eş-bütünleşme ilişkisinin var olduğu ise H1 hipotezi ile ifade edilmektedir. Durbin$\mathrm{H}$ panel testi ise, otoregresif parametresinin tüm kesitler için aynı olduğunu kabul eder. Bu testte eşbütünleşme ilişkisinin olmadığı H0 hipotezi ile tüm paneller için bir eş-bütünleşme ilişkisi olduğu da H1 hipotezi ile ifade edilir. Durbin-Hausman denklem (9) gösterilmiştir.

$$
\omega_{i}=\frac{1}{T-1} \sum_{j=M_{i}}^{M_{i}}\left(1-\frac{j}{M_{i}+1}\right) \sum_{t=j+1}^{T} v_{i t} v_{i t-j}
$$

Burada $\hat{v}_{i t}$ hata katsayısından elde edilen OLS kalıntılarını gösterirken, $M_{i}$ bant genişliği (bandwidth) parametresini göstermektedir. Durbin-H grup ve panel test $\left(D H_{g}, D H_{p}\right)$ istatistikleri aşağıda verilen denklem (10) aracılığıyla tahmin edilebilir.

$$
D H g=\sum_{i=1}^{n} S_{i}\left(\phi_{i}-\phi_{i}\right)^{2} \sum_{t=2}^{T} e_{i t-1}^{2} \text { ve } D H p=S_{n}(\phi-\phi)^{2} \sum_{i=1}^{n} \sum_{t=2}^{T} e_{i t-1}^{2}
$$


Tablo 5

Durbin H Eş Bütünleşme Testi Sonuçları

\begin{tabular}{llcc}
\hline & & Stat. & Prob. \\
\hline $\mathrm{Co} 2=f(\mathrm{FD}, \mathrm{GDP}$, & $\begin{array}{l}\text { Durbin-H Grup } \\
\begin{array}{l}\text { İstatistiği } \\
\text { Durbin-H Panel } \\
\text { Energy) }\end{array}\end{array}$ & -1.887 & $0.030^{* *}$ \\
& \begin{tabular}{l} 
İstatistiği \\
\hline
\end{tabular} & -1.537 & $0.056^{*}$ \\
\hline
\end{tabular}

Not: ${ }^{* *},{ }^{*}$ sırasıyla \%5 ve \%10 önem düzeyinde eş bütünleşme olduğunu ifade etmektedirler.

Tablo 5' incelendiğinde araştırma kapsamında yer alan ülkelere ait eş- bütünleşme test sonuçları görülmektedir. Bu sonuçlara göre her iki durumda da eş-bütünleşme ilişkisinin olmadığı yönündeki temel hipotez reddedilmiştir. Bu sonuçlara göre panelde yer alan ülkelerde eş-bütünleşme ilişkisinin olduğu söylenebilir.

\section{Uzun dönem ilişkisi katsayılarının tahmin edilmesi}

Çalışmada genişletilmiş ortalama grup (AMG-Augmented Mean Group) tahmincisinden yararlanılmıştır. Bu yöntem panelde heterojen eğim katsayısına izin veren ve aynı zamanda panelde yatay kesit bağımlılı̆̆ını dikkate alan bir tahmincidir (Eberhardt ve Bond, 2009; Eberhardt ve Teal, 2010; Bond ve Eberhardt, 2011). Bu tahmincinin matematiksel olarak gösterimi ise aşağıdaki gibidir.

$$
\beta_{A M G}=N^{-1} \sum_{\dot{I}=1}^{N} \beta_{t}
$$

$\beta_{\text {AMG }}$ yatay kesit tahmincilerinin ortalamalarını göstermektedir.

Tablo 6 incelendiğinde, Türkiye için finansal gelişmenin karbon salınımını azaltarak çevre kalitesini artırdığı, buna karşın ekonomik büyüme ve enerji tüketiminin ise karbon salınımını artırarak çevre kalitesini azalttığı tespit edilmiştir. Hindistan, Çin, Meksika ve Brezilya için panel sonuçları incelendiğinde ekonomik büyümenin karbon salınımını azaltarak çevre kalitesini artırdığı, buna karşın enerji tüketiminin ise karbon salınımını artırarak çevre kalitesini azalttığı tespit edilmiştir. Rusya için finansal gelişme ve enerji tüketiminin karbon salınımını azaltarak çevre kalitesini artırdı ğı, buna karşın ekonomik büyümenin ise karbon salınımını artırarak çevre kalitesini azalttığı tespit edilmiştir. Endonezya için ise finansal gelişme karbon salınımını azaltarak çevre kalitesini artırdığı tespit edilmiştir. Panel geneli incelendiğinde ise sadece enerji tüketiminin anlamlı olduğu tespit edilmiştir. Buna göre enerji tüketiminin karbon salınımını artırarak çevre kalitesini azalttığı tespit edilmiştir. 
Tablo 6

AMG Tahmincisi Sonuçları

\begin{tabular}{|c|c|c|c|c|}
\hline & FD & GDP & Energy & $\mathrm{C}$ \\
\hline \multirow[t]{3}{*}{ Türkiye } & $-0.007^{\star}$ & $0.00002^{\star}$ & $0.002^{\star * \star}$ & $-0,203$ \\
\hline & {$[0.004]$} & {$[0.00001]$} & {$[0.0001]$} & [0.127] \\
\hline & $(-1.74)$ & (1.68) & (19.93) & $(-1.58)$ \\
\hline \multirow[t]{3}{*}{ Hindistan } & 0,001 & $-0.0001^{\star * *}$ & $0.001^{\star * *}$ & 0,203 \\
\hline & {$[0.001]$} & {$[0.00004]$} & {$[0.0004]$} & {$[0.128]$} \\
\hline & $(0.87)$ & $(-2.61)$ & (3.23) & $(1.58)$ \\
\hline \multirow[t]{3}{*}{ Çin } & $-0,001$ & $-0.0001^{\star}$ & $0.001^{* * *}$ & $1.215^{\star * *}$ \\
\hline & [0.003] & {$[0.00007]$} & {$[0.0005]$} & {$[0.543]$} \\
\hline & $(-0.42)$ & $(-1.75)$ & $(2.81)$ & $(2.24)$ \\
\hline \multirow[t]{3}{*}{ Brezilya } & $8.93 \mathrm{e}-06$ & $-0.00002^{* * *}$ & $0.0003^{* * *}$ & 0,039 \\
\hline & {$[0.00006]$} & {$[3.79 \mathrm{e}-06]$} & {$[0.00005]$} & {$[0.028]$} \\
\hline & $(0.14)$ & $(-7.64)$ & $(7.53)$ & (1.39] \\
\hline \multirow[t]{3}{*}{ Endonezya } & $-0.001^{\star}$ & $3.80 \mathrm{e}-06$ & $-0,0001$ & $0.403^{\star * *}$ \\
\hline & {$[0.006]$} & {$[8.30 \mathrm{e}-06]$} & {$[0.0001[$} & [0.111] \\
\hline & $(-1.65)$ & $(0.46)$ & $(-0.62)$ & $(3.60)$ \\
\hline \multirow[t]{3}{*}{ Rusya } & $-0.032^{* * *}$ & $0.00006^{*}$ & $-0.0007^{\star *}$ & $5.377^{\star * *}$ \\
\hline & {$[0.010]$} & {$[0.00003]$} & {$[0.0003]$} & [1.480] \\
\hline & $(-2.99)$ & $(1.94)$ & $(-2.42)$ & $(3.82)$ \\
\hline \multirow[t]{3}{*}{ Meksika } & 0,0006 & $-0.00001^{\star * *}$ & $0.0001^{* * *}$ & $0.392^{\star * *}$ \\
\hline & [0.0003] & {$[1.55 \mathrm{e}-06]$} & {$[0.00002]$} & [0.048] \\
\hline & (1.95) & $(-12.21)$ & $(4.79)$ & $(8.75)$ \\
\hline \multirow[t]{3}{*}{ Panel } & $-0,005$ & $-0,0002$ & $0.0007^{\star}$ & 1,061 \\
\hline & {$[0.004]$} & {$[0.00002]$} & {$[0.0004]$} & {$[0.738]$} \\
\hline & $(-1.28)$ & $(-1.03)$ & $(1.66)$ & $(1.44)$ \\
\hline Wald chi2(3) & 11,85 & & & \\
\hline Prob $>$ chi2 & $0,007^{\star \star *}$ & & & \\
\hline
\end{tabular}

Not: ${ }^{* * * * *, *} \% 1, \% 5 \mathrm{ve} \% 10$ önem seviyesinde anlamlı olduklarını gösterir.

\section{Emirmahmutoğlu ve Köse (2011) Panel Nedensellik Analizi}

$\mathrm{Bu}$ çalışmada zaman serilerindeki, Toda-Yamamoto (1995) nedensellik analizi mantığına dayanan Emirmahmutoğlu ve Köse (2011) panel nedensellik analizi kullanılmıştır. Emirmahmutoğlu ve Köse (2011) nedensellik analizinde, Toda-Yamamoto (1995) nedensellik analizinde olduğu gibi değiş̧kenlerin birim kök içerip içermediği ve değişkenlerin eş-bütünleşik olup olmadıkları önemli değildir. Bu nedenle bu yöntem diğer yöntemlerden daha avantajlı bir yöntem olarak karşımıza çıkmaktadır. Emirmahmutoğlu ve Köse (2011) aşağıdaki gibi formül ize edilmektedir.

İki değişkenli VAR modeli aşağıdaki şekilde kurulmuştur

$$
x_{i, t}=\mu_{i}^{x}+\sum_{j=1}^{k_{i}+d \max _{i}} A_{11, i j} x_{i, t-j}+\sum_{j=1}^{k_{i}+d \max _{i}} A_{12, i j} y_{i, t-j}+v_{i, t}{ }^{x}
$$


$y_{i, t}=\mu_{i}^{y}+\sum_{j=1}^{k_{i}+d \max _{i}} A_{21, i j} x_{i, t-j}+\sum_{j=1}^{k_{i}+d \max _{i}} A_{22, i j} y_{i, t-j}+v_{i, t}{ }^{y}$

d max, sistemdeki her bir i için maksimum bütünleşme düzeyini gösterir.

Tablo 7

Karbondioksit Salınımı ve Ekonomik Büyüme Arasındaki Nedensellik Analizi Sonuçları

\begin{tabular}{lcclccl}
\hline & \multicolumn{2}{c}{ Co2 to GDP } & & \multicolumn{3}{c}{ GDP to Co2 } \\
\hline Ülkeler & Lag & Wald & p-val & Lag & Wald & p-val \\
\hline Türkiye & 3.000 & 4.697 & 0.195 & 3.000 & 8.543 & $0.036^{* *}$ \\
Hindistan & 3.000 & 11.223 & $0.011^{* *}$ & 3.000 & 0.578 & 0.902 \\
Çin & 3.000 & 0.100 & 0.992 & 3.000 & 6.961 & $0.073^{*}$ \\
Brezilya & 3.000 & 13.112 & $0.004^{* * *}$ & 3.000 & 4.452 & 0.217 \\
Endonezya & 3.000 & 3.049 & 0.384 & 3.000 & 5.543 & 0.136 \\
Rusya & 2.000 & 9.620 & $0.008^{* * *}$ & 2.000 & 0.384 & 0.825 \\
Meksika & 2.000 & 2.624 & 0.269 & 2.000 & 0.556 & 0.757 \\
Panel Fisher & & 37.389 & & & 20.071 & \\
p-value & \multicolumn{7}{c}{$0.001^{* * *}$} & & & $0.028^{* *}$ & \\
Not: ****** srass ile \%1, \%5 ve \%10 önem düzeyinde nedenselliğin olduğunu göstermektedir. &
\end{tabular}

Not: ${ }^{* * *},{ }^{* *},{ }^{*}$ sırası ile \%1, \%5 ve \%10 önem düzeyinde nedenselliğin olduğunu göstermektedir.

Tablo 7 sonuçlarına göre panel genelinde karbondioksit salınımı ve ekonomik büyüme arasında çift yönlü nedensellik tespit edilmiştir. Türkiye ve Çin için ekonomik büyümeden karbondioksit salınımına, Brezilya ve Rusya için ise karbondioksit salınımından ekonomik büyümeye doğru tek yönlü nedensellik tespit edilirken, Meksika ve Endonezya için herhangi bir nedensellik tespit edilememiştir.

Tablo 8

Karbondioksit Salınımı ve Enerji Tüketimi Arasındaki Nedensellik Analizi Sonuçları

\begin{tabular}{lcccccc}
\hline & \multicolumn{2}{c}{ Energy to Co2 } & & \multicolumn{2}{c}{ Co2 to Energy } \\
\hline Ülkeler & Lag & Wald & p-val & Lag & Wald & p-val \\
\hline Türkiye & 3.000 & 12.517 & $0.006^{* *}$ & 3.000 & 2.509 & 0.474 \\
Hindistan & 3.000 & 2.653 & 0.448 & 3.000 & 6.982 & $0.072^{\star}$ \\
Çin & 3.000 & 45.727 & $0.000^{* * *}$ & 3.000 & 3.245 & 0.355 \\
Brezilya & 3.000 & 2.045 & 0.563 & 3.000 & 2.821 & 0.420 \\
Endonezya & 2.000 & 0.150 & 0.928 & 2.000 & 0.433 & 0.805 \\
Rusya & 2.000 & 0.312 & 0.855 & 2.000 & 14.873 & $0.001^{* * *}$ \\
Meksika & 3.000 & 1.513 & 0.679 & 3.000 & 4.546 & 0.208 \\
Panel Fisher & & 56.600 & & & 28.991 & $0.010^{* *}$ \\
p-value & & $0.000^{* * *}$ & & & & \\
\hline
\end{tabular}

Not: ${ }^{* * *, * *},{ }^{*}$ sırası ile \%1, \%5 ve \%10 önem düzeyinde nedenselliğin olduğunu göstermektedir. 
Tablo 8 sonuçlarına göre karbon salınımı ve enerji tüketimi arasında çift yönlü nedensellik tespit edilmiştir. Ülke bazlı incelendiğinde, Türkiye ve Çin için enerji tüketiminden karbon salınımına, Hindistan ve Rusya için ise karbon salınımından enerji tüketimine doğru tek yönlü nedensellik tespit edilmiştir. Meksika ve Endonezya içinde herhangi bir nedensellik tespit edilememiştir.

Tablo 9

Finansal Gelişme ve Karbondioksit Salınımı Arasındaki Nedensellik Analizi Sonuçları

\begin{tabular}{lcclccc}
\hline & \multicolumn{2}{c}{ FD to Co2 } & & \multicolumn{3}{c}{ Co2 to FD } \\
\hline Ülkeler & Lag & Wald & p-val & Lag & Wald & p-val \\
\hline Türkiye & 3.000 & 7.565 & $0.056^{\star}$ & 3.000 & 2.119 & 0.548 \\
Hindistan & 3.000 & 10.392 & $0.016^{\star *}$ & 3.000 & 8.038 & $0.045^{\star *}$ \\
Çin & 2.000 & 30.655 & 0.721 & 2.000 & 1.378 & 0.502 \\
Brezilya & 3.000 & 15.685 & $0.001^{\star * *}$ & 3.000 & 16.927 & $0.001^{* * *}$ \\
Endonezya & 3.000 & 4.005 & 0.261 & 3.000 & 0.954 & 0.812 \\
Rusya & 1.000 & 0.067 & 0.795 & 1.000 & 2.072 & 0.150 \\
Meksika & 2.000 & 1.494 & 0.474 & 2.000 & 0.172 & 0.917 \\
Panel Fisher & \multicolumn{7}{c}{32.671} & & & 27.594 & $0.016^{* *}$ \\
p-value & $0.003^{* * *}$ & & & & \\
\hline
\end{tabular}

Not: ${ }^{* * *, * *, *}$ sırası ile $\% 1, \% 5$ ve $\% 10$ önem düzeyinde nedenselliğin olduğunu göstermektedir.

Tablo 9 incelendiğinde finansal gelişme ve karbon salınımı arasında çift yönlü bir nedensellik tespit edilmiştir. Sonuçlar ülke bazlı incelendiğinde, Hindistan ve Brezilya için çift yönlü nedensellik tespit edilirken, Türkiye için tek yönlü ve finansal gelişmeden karbon salınımına doğru bir nedensellik tespit edilmiştir. Çin, Endonezya, Rusya ve Meksika için ise her hangi bir nedensellik tespit edilememiştir.

\section{Sonuç ve Değerlendirme}

Bu çalışmanın amacı, 1990-2014 dönemi için Türkiye, Çin, Hindistan, Endonezya, Brezilya, Rusya ve Meksika ekonomileri için finansal gelişmenin, ekonomik büyümenin ve enerji tüketimin çevre kalitesi üzerindeki etkisini incelemektir. Çalışmada öncelikle uygun ekonometrik testlerin seçilmesi amacı ile yatay kesit bağımlılığı testi yapılmış, değişken ve modellerde yatay kesit bağımlılığı olduğundan dolayı yatay kesit bağımlılığını dikkate alan testler kullanılmıştır.

Analiz bulguları incelendiğinde; Türkiye, Endonezya ve Rusya için finansal gelişmenin çevre kalitesini artırdığı tespit edilmiştir. $\mathrm{Bu}$ sonuçlar finansal gelişmenin $\mathrm{CO} 2$ emisyonunu azaltmada ve emisyondaki değişmeleri öngörmede anlamlı ve önemli bir etkisi olduğunu ortaya koymuştur. Yine bu sonuçlar, küresel iklim değişikliği ile mücadele konusunda önemli bir politika aracı olabileceğini göstermektedir (Koçak, 2017: 549). Analiz sonuçları, Koçak (2017), Yuxiang ve Chen (2011), Tamazian ve Rao (2010) ve Tamazian vd., (2009)'nin daha fazla finansal gelişmenin $\mathrm{CO} 2$ salınımlarını azaltmada dikkate değer bir gösterge olduğu yönündeki hipotezlerini de destekler niteliktedir.

Ekonomik büyüme sonuçları incelendiğinde ise; Hindistan, Çin, Brezilya ve Meksika için ekonomik büyümenin karbon salınımını azaltarak çevre kalitesini artırdığı tespit edilmiştir. Anılan bu ülkeler hızlı gelişmekte olan ülke sınıfında yer aldığından dolayı yeni düşük karbon teknolojilerini geliştirme ve kullanabilme potansiyeline sahip olabildiklerinden, çevre dostu teknolojileri kullanmaları sonucu ekonomik büyümenin karbon salınımını azaltarak çevre kalitesini artırdığı söylenebilir. Çünkü bu ülkeler çevre dostu teknolojileri kullanarak uzun vadede daha düşük $\mathrm{CO} 2$ emisyonlarda aynı üretim seviyelerine ulaşabileceklerdir. Analiz sonuçları, Narayan vd. (2016) 181 ülke ekonomisi için yapmış oldukları, 
Kasperowicz (2015) 18 AB üyesi ülkeler için yapmış olduğu, Fotros ve Maaboudi (2010) İran ekonomisi için yapmış oldukları, Carson vd. (1997) ABD ekonomisi için yapmış oldukları çalışmaların sonuçlarını destekler niteliktedir.

Türkiye ve Rusya için ise ekonomik büyümenin karbon salınımını artırarak çevre kalitesini azalttığı tespit edilmiştir. Kuznets (1955) 'e göre esnek çevre yasaları nedeni ile yatırımcıların gelişmemiş veya gelişmekte olan ülkelere yöneldiği ifade edilmiştir. Bu bağlamda yatırımcılar bu ülkelerde çevreye önem vermeyerek eski teknolojileri kullanmakta ve çevreyi kirleterek çevre kalitesini azaltmaktadırlar. Ancak zamanla artan gelirin etkisi ile insanların çevreye duyarlı hale geldiği ve yatırımcıların da çevreye duyarlı olmaya zorlandığı görülmektedir. Bu bağlamda sonuçlar incelendiğinde Türkiye ve Rusya için halen istenilen gelir düzeyine ulaşılmadığı söylenebilmektedir. Özellikle fosil enerji kaynaklarının kullanılması hava kalitesinin bozulmasına yol açmaktadır. Bu bağlamda sonuçlar incelendiğinde genel olarak enerji tüketiminin çevre kalitesini bozduğu tespit edilmiştir. Ancak Rusya'da kullanılan enerjinin çevre kalitesini artırdığ tespit edilmiştir. Bunun nedenin ise doğalgaz zengini olan Rusya'nın daha çok doğalgaz kullanmasından kaynaklandığ düşünülmektedir. Analiz sonuçları, Çetin ve Şeker (2014) Türkiye ekonomisi için yapmış oldukları, Topallı (2016) Hindistan, Çin, Brezilya ve Güney Afrika ülke ekonomileri için yapmış oldukları çalışmaları destekler niteliktedir.

Çalışmanın nedensellik sonuçları incelendiğinde, modelin bütünü için karbondioksit salınımı ile ekonomik büyüme arasında çift yönlü bir nedensellik olduğu tespit edilmiştir. Türkiye ve Çin ekonomileri için ekonomik büyümeden karbondioksit salınımına, Brezilya ve Rusya ekonomileri için ise karbondioksit salınımından ekonomik büyümeye doğru tek yönlü nedensellik tespit edilirken, Meksika ve Endonezya ekonomileri içinde herhangi bir nedensellik tespit edilememiştir. Aynı şekilde modelin geneli için, karbon salınımı ve enerji tüketimi arasında çift yönlü nedensellik tespit edilmiştir. Ülke bazlı incelendiğinde ise, Türkiye ve Çin ekonomilerinde enerji tüketiminden karbon salınımına, Hindistan ve Rusya ekonomilerinde karbon salınımından enerji tüketimine doğru tek yönlü nedensellik tespit edilirken, Meksika ve Endonezya ekonomileri için herhangi bir nedensellik tespit edilememiştir. Yine modelin geneli açısından, finansal gelişme ile karbon salınımı arasında çift yönlü bir nedensellik tespit edilmiştir. Ülke bazlı değerlendirildiğinde ise, Hindistan ve Brezilya ekonomileri için çift yönlü nedensellik tespit edilirken, Türkiye ekonomisi için tek yönlü ve finansal gelişmeden karbon salınımına doğru bir nedensellik tespit edilmiştir. Çin, Endonezya, Rusya ve Meksika ekonomileri için ise her hangi bir nedensellik tespit edilememiştir.

$\mathrm{Bu}$ çalışma sonuçları, politika yapıcıların uzun vadede sera gazı salınımlarını azaltacak finansal politikalar tasarlamaları gerektiğini göstermiştir. İklim değişikliği ile mücadelede yenilenebilir enerji proje fonları geliştirerek bunların desteklenmesi teşvik edilebilir. Ayrıca BRICS-TM ülkeleri için yeşil teknoloji transferini, yenilenebilir enerji sektörüne doğrudan yabancı yatırımı, yeşil altyapıyı desteklemek için finansal gelişmeyi ve yenilenebilir enerji kaynaklarını kullanarak enerji üretimini destekleyen politikalar önerilmektedir. Çalışmada enerji ekonomisi literatüründe önerildiği gibi çevre kalitesinin bir göstergesi olarak karbon emisyonu seviyesi kullanmıştır. Bununla birlikte, alternatif sonuçlara ulaşmak için geliştirilebilecek veya önerilebilecek çevresel kalite ( pm10, p.2,5 vb.) seviyesi için alternatif değişkenler bulunmaktadır. Bu nedenle, çevresel kalite için alternatif ölçümler kullanılarak daha fazla araştırmalar yapılabilir. Aynı şekilde sonuçların genellenebilmesi için gelir düzeyi farklı ülke ekonomileri kıyaslanarak araştırılabilir. 


\section{Kaynakça}

Akbostanci, E., Turut-Asik, S. ve Tunc, GI. (2009). The relationship between income and environment in Turkey: İs there an environmental Kuznets curve? Energy Policy, 37(3), 861-867. doi:10.1016/j.enpol.2008.09.088

Al-Amin, S.C., Huda, N. ve Hamid, A. (2009). Trade, economic development and environment: Malaysian experience. Bangladesh Dev Stud., 32(3), 19-39. Erişim adresi: https://bids.org.bd/uploads/publication/BDS/32/32-3/02_Amin_Siwar_Huda\& \%20 Hamid.pdf

Al-Mulali, U., Saboori, B. ve Ozturk, I. (2015). Investigating the environmental Kuznets Curve hypothesis in Vietnam. Energy Policy, 76, 123-131. doi:10.1016/j.enpol.2014.11.019

Akin, C.S. (2014). The impact of foreign trade, energy consumption, and income on CO2 emissions. Int J Energy Econ Policy, 4(3), 465-475. Erişim adresi: https://dergipark.org.tr/en/download/articlefile/361330

Babu, S.S. ve Datta, S.K. (2013). The Relevance of environmental Kuznets Curve (EKC) in a framework of Broad-Based environmental degradation and modified measure of growth-a pooled data analysis. International Journal of Sustainable Development \& World Ecology, 20(4), 309-316. doi:10.1080/13504509.2013.795505

Breusch, T. S. ve Pagan, A. R. (1980). The lagrange multiplier test and its applications to model specification in econometrics. The Review of Economic Studies, 47(1), 239-253. https://doi.org/10.2307/2297111

Carson, R.T. (2010). The environmental Kuznets curve: seeking empirical regularity and theoretical structure. Review of Environmental and Economic Policy, 4, 3-23. doi:10.1093/reep/rep021

Carson R. T., Jeon, Y. ve McCubbin, D. R. (1997). The relationship between air pollution emissions and income: US data. Cambridge University Press Environment and Development Economics, 2, 433-450. Erişim adresi: https://econweb.ucsd.edu/ rcarson/papers/USKuznets.pdf

Cialani, C. (2007). Economic growth and environmental quality. Management of Environmental Quality: An International Journal,18(5), 568-577. https://doi.org/10.1108/14777830710778328

Çetin, M., Kırcı, B., Saygın, S. ve Alaşahan, Y. (2018). Ekonomik büyüme, finansal gelişme, enerji tüketimi ve dış ticaretin çevre kirliliği üzerindeki etkisi: Türkiye ekonomisi için bir nedensellik analizi (1960-2013). Balkan Journal of Social Sciences/Balkan Sosyal Bilimler Dergisi, 7(13), 26-43. Erişim adresi: http://hdl.handle.net/20.500.11776/2706

Çetin, M. ve Şeker, F. (2014). Ekonomik büyüme ve dış ticaretin çevre kirliliği üzerindeki etkisi: Türkiye için bir ARDL sinır testi yaklaşımı. Yönetim ve Ekonomi, 21(2), 213-230. https://doi.org/10.18657/yecbu.48366

Dar, J. A. ve Asif, M. (2018). Does financial development improve environmental quality in Turkey? An application of endogenous structural breaks based cointegration approach. Management of Environmental Quality: An International Journal, 29(2), 368-384.

doi:10.1108/MEQ-02-2017-0021

Eberhardt, M. ve Teal, F. (2010). Productivity analysis in global manufacturing production. Discussion Paper 515, University of Oxford. Erişim adresi: http://www.economics.ox.ac.uk/research/WP/pdf/ paper515.pdf 
Eberhardt, M. ve Teal, F. (2011). Econometrics for grumblers: A new look at the literature on crosscountry growth empirics. Journal of Economic Surveys, 25, 109-155. doi:10.1111/j.1467-6419.2010.00624.x

Eberhardt, M. ve Bond, S. (2009). Cross-section dependence in nonstationary panel models: A novel estimator. MPRA Paper 17692, University Library of Munich.

Emirmahmutoğlu, F. ve Köse, N. (2011). Testing for Granger causality in heterogeneous mixed panels. Economic Modelling, 28, 870-876. doi:10.1016/j.econmod.2010.10.018

Fotros, M. H. ve Maaboudi, R. (2010). The Impact of Trade Openness on CO2 Emissions in Iran, 1971-2005. Erişim adresi: https://www.gtap.agecon.purdue.edu/resources/download/5112.pdf

Grossman, G.M. ve Krueger, A.B. (1991). Environmental Impacts of a North American Free Trade Agreement. NBER Working Paper, No. 3914; National Bureau of Economic Research: Cambridge, MA, USA.

Holtz-Eakin, D. ve Seldan, T.M. (1995). Stoking the fires? CO2 emissions and economic growth. Journal of Public Economics, 57(1), 85-101. doi:10.1016/0047-2727(94)01449-X

Irfan, M. ve Shaw, K. (2017). Modeling the effects of energy consumption and urbanization on environmental pollution in South Asian countries: a nonparametric panel approach. Qual Quant, 51(1), 65-78. doi:10.1007/s11135-015-0294-x

Jalil, A. ve Feridun, M. (2011). The impact of growth, energy and financial development on the environment in China: a cointegration analysis. Energy Economics, 33(2), 284-291. doi:10.1016/j.eneco.2010.10.003

Jamel, L. ve Derbali, A. (2016). Do energy consumption and economic growth lead to environmental degradation? Evidence from Asian economies. Cogent Economics \& Finance, 4, 1-19. doi:10.1080/23322039.2016.1170653

Jiang, M., Kim, E. ve Woo, Y. (2020). The Relationship between Economic Growth and Air Pollution-A Regional Comparison between China and South Korea. International Journal of. Environmetal Research adn Public Health, 17, 1-20. doi:10.3390/ijerph17082761

Karanfil, F. (2009). How many times again will we examine the energy income nexus using a limited range of traditional econometric tools? Energy Policy, 37(4), 1191-1194. doi:10.1016/j.enpol.2008.11.029

Kasperowicz, R. (2015). Economic growth and CO2 emissions: the ECM analysis. Journal of International Studies, 8(3), 91-98. doi: 10.14254/2071-8330.2015/8-3/7

Khan, S., Peng, Z. ve Li, Y. (2019). Energy consumption, environmental degradation, economic growth and financial development in globe: Dynamic simultaneous equations panel analysis. Energy Reports, 5, 1089-1102. doi:10.1016/j.egyr.2019.08.004

Kraft, J. ve Kraft, A. (1978), On the Relationship between Energy and GNP. Journal of Energy Development, 3, 401-403. Erişim adresi: https://www.jstor.org/stable/24806805

Koçak, E. (2017). Finansal gelişme çevresel kaliteyi etkiler mi? Yükselen piyasa ekonomileri için ampirik kanıtlar. Uluslararası Yönetim İktisat ve Isşletme Dergisi, 13(3), 535-552. doi:10.17130/ijmeb.2017331326

Koçbulut, Ö. ve Altıntaş, H. (2016). İkiz açılar ve Feldstein-Horioka hipotezi: OECD ülkeleri üzerine yatay kesit bağımlılığı altında yapısal kırılmamı eşbütünleşme analizi. Erciyes Üniversitesi İktisadi ve İdari Bilimler Fakültesi Dergisi, 48, 145-174. Erişim adresi: https://dergipark.org.tr/tr/download/articlefile/282798

Kuznets, S. (1955). Economic growth and income inequality. The American Economic Review, 45(1), 1-28. Erişim adresi: https://assets.aeaweb.org/asset-server/files/9438.pdf 
Lee, C.C. ve Chang, C.P. (2008). Energy consumption and economic growth in Asian economies: A more comprehensive analysis using panel data. Resource and Energy Economics, 30, 50-65. doi:10.1016/j.reseneeco.2007.03.003

Li, S., Zhang, J. ve Ma, Y. (2015). Financial development, environmental quality and economic growth. Sustainability, 7, 9395-9416. doi:10.3390/su7079395

Lieb, C.M. (2003). The environmental Kuznets Curve: A survey of the empirical evidence and of possible cause. Discussion Paper Series No. 391, University of Heidelberg, Erişim adresi: https://www.econstor.eu/bitstream/10419/127208/1/dp391.pdf

Meadows, DH., Meadows, DL., Randers, J. ve Behrens, WW. (1972). The limits to growth. New York: Universe Books.

Munir, K. ve Riaz, N. (2019). Energy consumption and environmental quality in South Asia: evidence from panel non-linear ARDL. Environmental Science and Pollution Research, 26, 29307-29315. doi:10.1007/s11356-019-06116-8

Narayan, P.K., Saboori, B. \& Soleymani, A. (2016). Economic growth and carbon emissions. Economic Modelling, 53, 388-397. doi.10.1016/j.econmod.2015.10.027

Pesaran, M. H. ve Yamagata, T. (2008). Testing slope homogeneity in large panels. Journal of Econometrics, 142(1), 50-93. doi:10.1016/j.jeconom.2007.05.010

Pesaran, M. H., Ullah, A. ve Yamagata, T. (2008). A bias-adjusted LM test of error cross- section independence. The Econometrics Journal, 11(1), 105-127. Erişim adresi: https://economics.ucr.edu/papers/papers06/06-03.pdf

Pesaran, M. H. (2004). General diagnostic tests for cross section dependence in panels. Cambridge Working Papers in Economics no. 435. University of Cambridge. Erişim adresi: http://ftp.iza.org/dp1240.pdf

Sadorsky, P. (2010). The impact of financial development on energy consumption in emerging economies. Energy Policy, 38(5), 2528-2535. doi:10.1016/j.enpol.2009.12.048

Saidi, K. ve Hammami, S. (2015). The impact of CO2 emissions and economic growth on energy consumption in 58 countries. Energy Rep, 1, 62-70. doi:10.1016/j.egyr.2015.01.003

Sehrawat, M., Giri, A.K. ve Mohapatra, G. (2015). The impact of financial development, economic growth and energy consumption on environmental degradation. Management of Environmental Quality: An International Journal, 26(5), 666-682. doi:10.1108/MEQ-05-2014-0063

Sekali, J. ve Bouzahzah, M. (2019). Financial development and environmental quality: Empirical evidence for Morocco. International Journal of Energy Economics and Policy, 9(2), 67-74. doi:10.32479/ijeep.7266

Shahbaz, M., Shahzad, S. J. H., Ahmad, N. ve Alam, S. (2016). Financial development and environmental quality: The way forward. Energy Policy, 98, 353-364. doi:10.1016/j.enpol.2016.09.002

Shoaib, H.M., Rafique , Z.M., Nadeem, A. M. ve Huang, S. (2020). Impact of financial development on CO2 emissions: A comparative analysis of developing countries (D8) and developed countries (G8). Environmental Science and Pollution Research, 27, 12461-12475. doi:10.1007/s11356-019-06680-z

Soytas, U. ve Sari, R. (2003). Energy consumption and GDP: Causality relationship in G7 countries and emerging markets. Energy Economics, 25, 33-37. doi:10.1016/S0140-9883(02)00009-9

Stern, D. I. (2004). The rise and fall of the environmental Kuznets curve. World Development, 32, 1419-1438. doi:10.1016/j.worlddev.2004.03.004 
Şahin, D. (2018). D-8 ülkelerinde finansal gelişme ve ticari açılklğın çevresel kalite üzerine etkisi: Panel veri analizi. Dicle Üniversitesi İktisadi ve İdari Bilimler Fakültesi Dergisi, 8(15), 48-67. Erişim adresi: https://dergipark.org.tr/tr/download/article-file/497401

Tahir, T., Luni, T., Majeed, M.T. ve Zafar, A. (2021). The impact of financial development and globalization on environmental quality: evidence from South Asian economies. Environmental Science and Pollution Research, 28, 8088-8101. doi:10.1007/s11356-020-11198-w

Tamazian, A., ve Rao, B. B. (2010). Do economic, financial and institutional developments matter for environmental degradation? Evidence from transitional economies. Energy Economics, 32(1), 137-145. doi:10.1016/j.eneco.2009.04.004

Tamazian, A., Chousa, J. P., ve Vadlamannati, K. C. (2009). Does higher economic and financial development lead to environmental degradation: Evidence from BRIC countries. Energy Policy, 37(1), 246-253. doi:10.1016/j.enpol.2008.08.025

Temelli, F. ve Şahin, D. (2019). Yükselen piyasa ekonomilerinde finansal gelişme, ekonomik büyüme ve teknolojik gelişmenin çevresel kalite üzerine etkisinin analizi. Karabük Üniversitesi Sosyal Bilimler Enstitüsü Dergisi, 9(2), 577-593. doi:10.14230/joiss706

Topallı, N. (2016). CO2 emisyonu ve ekonomik büyüme arasındaki ilişki: Hindistan, Çin, Brezilya ve Güney Afrika için panel veri analizi. Çankırı Karatekin Üniversitesi İİBF Dergisi, 6(1), 427-447. doi: $10.18074 /$ cnuiibf. 275

Westerlund, J. (2008). Panel cointegration tests of the Fisher effect. Journal of Applied Econometrics, 23(2), 193-233. doi:10.1002/jae.967

Yang, J., Zhang, Y. ve Meng, Y. (2015). Study on the impact of economic growth and financial development on the environment in China. Journal of Systems Science and Information, 3(4), 334-347. doi: $10.1515 /$ jssi-2015-0334

Yuxiang, K. ve Chen, Z. (2011). Financial Development and Enviromental Performance: Evidence from China. Environment and Development Economics, 16(1), 93-111. doi:10.1017/S1355770X10000422

Zafar, M.W., Saud, S. ve Hou, F. (2019). The impact of globalization and financial development on environmental quality: evidence from selected countries in the Organization for Economic Cooperation and Development (OECD). Environmental Science and Pollution Research, 26,13246-13262. doi:10.1007/s11356-019-04761-7

\section{Extended Abstract}

\section{Purpose}

The economic and financial development levels of the countries affect the amount and type of energy used. Features such as the type and level of energy used can have an impact on environmental quality. Negative environmental quality affects many factors, especially climate and living things. For all these reasons, this study is deemed necessary. The aim of this study is to examine the impact of financial development, economic growth and energy consumption on environmental quality for the economies of Turkey, China, India, Indonesia, Brazil, Russia and Mexico for the period 1990-2014.

\section{Design and Methodology}

The data set of the research is created using annual data for the period 1990-2014. In the study, the reason for limiting the data set in 2014 is that the carbon dioxide emission data is until 2014. In the model created within the scope of the research; As a measure of environmental quality, carbon dioxide emissions per capita (CO2), representing financial development (FD), the ratio of loans to the private sector to GDP, representing economic growth (GDP), annual increase in economic growth, representing energy consumption (Energy) per 
capita oil consumption is used. The data used in the study were obtained from the World Bank database. First, the cross-section independence and homogeneity of the variables are examined to decide which analysis methods to use. Cross-section independence was examined using the Peseran, Ullah, and Yagamata (2008), Peseran (2004) LM, Peseran (2004) CD, and Breusch and Pagan (1980) LM tests. The homogeneity test is examined with the delta test developed by Pesaran and Yamagata (2008). Since the variables and the model contain cross-sectional dependencies and the slope coefficients of the model are heterogeneous, tests that consider cross-sectional dependence and heterogeneity are used. To test the stationarity of the variables, Pesaran (2007) CADF (Crosssectional Augmented Dickey Fuller) test, one of the 2nd generation panel unit root tests that takes into account the cross-sectional dependence, is used. After satisfying the stationarity conditions of the variables, the long-term relationship between them is examined by Westerlund (2008) Durbin-H cointegration test. The extended mean group (AMG-Augmented Mean Group) method is used to estimate the long-term correlation coefficients. Again, causality test between variables is tested with Emirmahmutoğlu and Köse (2011) panel causality analysis based on the Toda-Yamamoto (1995) causality analysis logic.

\section{Findings}

According to the analysis results, it has been determined that there is a cointegration relationship in the countries included in the panel. It has been determined that financial development increases environmental quality by reducing carbon emissions for Turkey, while economic growth and energy consumption increase carbon emissions and reduce environmental quality. For India, China, Mexico and Brazil, it has been determined that economic growth improves environmental quality by reducing carbon emissions, while energy consumption decreases environmental quality by increasing carbon emissions. For Russia, it has been determined that financial development and energy consumption increase environmental quality by reducing carbon emissions, while economic growth reduces environmental quality by increasing carbon emissions. For Indonesia, financial development has been found to reduce carbon emissions and improve environmental quality. When the causality analysis results are examined, it has been determined that there is a bidirectional causality relationship between carbon dioxide emissions and economic growth, carbon emissions and energy consumption and financial development and carbon emissions across the panel.

\section{Research Limitations}

The most important limitation of the study is that data on carbon dioxide emissions are available until 2014.

\section{Implications}

The carbon emission level is used as an indicator of environmental quality. However, there are alternative variables for the environmental quality level (such as pm10, p.2,5) that can be developed or suggested to reach alternative results. Therefore, further research can be conducted using alternative measures for environmental quality. In the same way, in order to generalize the results, the income level can be investigated by comparing the economies of different countries. The results of the study revealed that energy consumption negatively affects environmental quality by increasing carbon emissions. This situation shows that especially policy makers should develop policies that encourage the use of environmentally friendly renewable energy sources.

\section{Originality Value}

There are theoretical and empirical studies on the impact of financial development and economic growth on environmental quality. However, the absence of a study on the E-7 countries, which have a rapidly rising and growing economy, shows that this study is an original study.

Araştırmacı Katkısı: Fahrettin PALA (\%50), Abdulkadir BARUT (\%50). 